\title{
Formic Acid Electro-Oxidation Catalyzed by PdNi/Graphene Aerogel
}

\author{
Yufei Bao, Ligang Feng * \\ School of Chemistry and Chemical Engineering, Yangzhou University, Yangzhou 225002, Jiangsu Province, China.
}

\begin{abstract}
Direct formic acid fuel cells involve two significant half-reactions, namely formic acid electro-oxidation and oxygen reduction reaction, and the more sluggish and complex process for anode formic acid oxide also determine the whole fuel cells energy conversion efficiency. The most efficient catalysts rely on the noble metal of $\mathrm{Pt}$ and $\mathrm{Pd}$ based catalysts and compared with $\mathrm{Pt}$ catalysts, $\mathrm{Pd}$ catalyst is more appealing because of the low $\mathrm{CO}$ poisoning effect during the electro-oxidation of formic acid that mainly follows the direct pathway. The Pd alloy effect and support effect should be considered for the catalyst fabrication since the resulted structure and electronic modification could largely increase the catalytic performance. Graphene emerges out as novel support while the easy

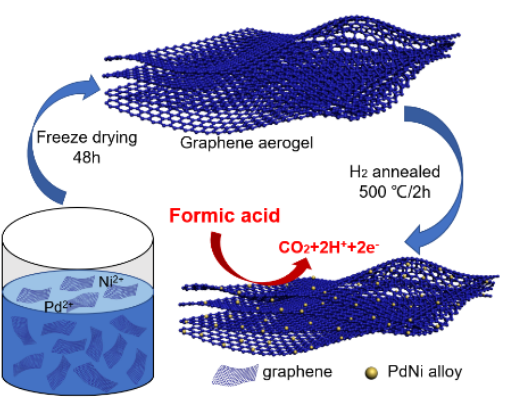
agglomeration and destruction of pure graphene do not guarantee promising merits. In this work, we demonstrated the formic acid oxidation ability boosting by facile coupling PdNi alloy and 3D graphene aerogel (PdNi/GA) via a freezingdrying/thermal annealing reduction approach. The PdNi alloy crystal structure was well confirmed by the X-ray diffractions technique and the alloy nanoparticles were successfully anchored on the 3D graphene aerogel surface. The electrochemical performance was evaluated for formic acid oxidation in the acid electrolyte. The PdNi/GA catalyst displayed a larger peak current density of $136 \mathrm{~mA} \cdot \mathrm{cm}^{-2}$, which was 2 and 3.45 times greater than $\mathrm{Pd} / \mathrm{GA}\left(68 \mathrm{~mA} \cdot \mathrm{cm}^{-2}\right)$ and $\mathrm{Pd} / \mathrm{C}$ (39.4 $\left.\mathrm{mA} \cdot \mathrm{cm}^{-2}\right)$, respectively. The anti-CO poisoning ability was measured by CO stripping technique, and a low onset potential of $0.49 \mathrm{~V}$ was found on $\mathrm{PdNi} / \mathrm{GA}$ catalyst, about $120 \mathrm{mV}$ less than that of $\mathrm{Pd} / \mathrm{GA}$ catalyst, indicating the oxophilic property of $\mathrm{Ni}$ to assist formic acid oxidation via the bi-functional mechanism. The oxidation peak potential of $0.67 \mathrm{~V}$ was observed on $\mathrm{PdNi} / \mathrm{GA}$, about $40 \mathrm{mV}$ less than that of $\mathrm{Pd} / \mathrm{C}$ catalyst, indicating the merits of $3 \mathrm{D}$ structure of graphene. Moreover, PdNi/GA catalyst had the highest mass activity of $1699 \mathrm{~mA} \cdot \mathrm{mg}^{-1}$ compared to $\mathrm{Pd} / \mathrm{GA}\left(851 \mathrm{~mA} \cdot \mathrm{mg}^{-1}\right)$ and Pd/C $\left(537 \mathrm{~mA} \cdot \mathrm{mg}^{-1}\right)$ catalysts. The specific activity of PdNi/GA was $2.6 \mathrm{~mA} \cdot \mathrm{cm}^{-2}$, which was 1.94 and 2.7 times of $\mathrm{Pd} / \mathrm{GA}(1.34$ $\left.\mathrm{mA} \cdot \mathrm{cm}^{-2}\right)$ and $\mathrm{Pd} / \mathrm{C}\left(0.96 \mathrm{~mA} \cdot \mathrm{cm}^{-2}\right)$ catalysts. The highly improved catalytic performance could be due to the combined alloy and support effect. The PdNi/GA was a promising catalyst for application in the direct formic acid fuel cells.
\end{abstract}

Key Words: Formic acid oxidation reaction; Direct formic acid fuel cell; Electrocatalyst; Pd-base catalyst; Graphene aerogel

\section{$\mathrm{PdNi} /$ 石墨烯气凝胶电催化甲酸氧化}

\author{
包玉菲，冯立纲 ${ }^{*}$ \\ 扬州大学化学化工学院, 江苏扬州 225002
}

摘要: 甲酸电氧化性能提升对发展直接甲酸燃料池至关重要。本文首次报道了采用简便的冷冻干燥/退火还原的方法将 $\mathrm{PdNi}$ 合金与三维石墨烯气凝胶进行了高效耦合并实现了对甲酸氧化反应的高效催化。利用X射线衍射、扫描电镜和透射

Received: August 13, 2020; Revised: September 8, 2020; Accepted: September 8, 2020; Published online: September 14, 2020.

${ }^{*}$ Corresponding author. Email: ligang.feng@yzu.edu.cn; Tel.: +86-17306299692.

The project was supported by the National Natural Science Foundation of China (21972124, 21603041).

国家自然科学基金(21972124, 21603041)资助项目

(C) Editorial office of Acta Physico-Chimica Sinica 
电镜等仪器对催化剂的结构和形貌进行了表征, 并对其催化甲酸氧化反应的性能进行了研究。PdNi以合金纳米粒子形式 分散在三维石墨烯气凝胶(PdNi/GA)表面, PdNi/GA催化剂中Pd的XPS能谱有明显的位移, 表明Pd, Ni和石墨烯气凝胶 载体之间有较强的电子相互作用。电化学测试结果表明PdNi/GA催化剂具有很高的的甲酸电氧化性能, 其峰值电流密度 为 $136 \mathrm{~mA} \cdot \mathrm{cm}^{-2}$, 分别是 $\mathrm{Pd} / \mathrm{GA}\left(68 \mathrm{~mA} \cdot \mathrm{cm}^{-2}\right)$ 和 $\mathrm{Pd} / \mathrm{C}\left(39.4 \mathrm{~mA} \cdot \mathrm{cm}^{-2}\right)$ 的2倍和3.45倍。在CO溶出伏安测试中, $\mathrm{PdNi} / \mathrm{GA}$ 催化剂的起始电位和峰电位分别是 0.49 和 $0.67 \mathrm{~V}$, 证明PdNi/GA催化剂具有优异的抗CO毒化能力。 $\mathrm{PdNi} / \mathrm{GA}$ 良好的催化 性能可以归因于石墨烯三维结构提供的优异的分散性及导电性和钯镍合金抗CO中毒能力的提升。

关键词: 甲酸氧化反应; 直接甲酸电池; 电催化剂; 钯基催化剂; 石墨烯气凝胶 中图分类号: 0646

\section{Introduction}

Formic acid electro-oxidation is a significant fundamental reaction in the development of the energy-relevant device, especially for the direct formic acid fuel cells ${ }^{1-3}$. To efficiently catalyze this reaction, catalysts are required and the most efficient materials relied on the noble metal of Pt and Pd based catalysts ${ }^{4,5}$. It was recognized that Pt catalysts exhibited poor catalytic performance arising from $\mathrm{CO}$ poisoning accumulated by the dehydration step ${ }^{6-8}$. Compared with Pt catalysts, the electro-oxidation of formic acid on Pd catalysts is mainly performed through the direct pathway, thus it has a very low $\mathrm{CO}$ poisoning effect ${ }^{9}$. Therefore, lots of researches have been done on Pd by structure/morphology/composition modifying with other materials, yet challenging is still faced for the anti-CO poisoning ability promotion.

Alloying with transition metals is regarded as an effective way to enhance the catalytic capability for formic acid electrooxidation. Attention has been directed to the surface modification, shape engineering, and structure optimization for this kind of catalysts ${ }^{10,11}$. The resulted alloyed catalyst exhibited superior catalytic performance to that of its single counterpart, because of the electronic modification resulting from the lowed D-band center ${ }^{12}$. Moreover, the oxophilic property of the second element could readily promote the formation of oxygencontaining species at a low potential as interpreted by the bifunctional mechanism for the poisoning intermediates oxidation-removal ${ }^{13,14}$. That could be interpreted simply in the below mechanism for a Pd-M (metal) alloy catalyst.

$\mathrm{Pd}+\mathrm{HCOOH} \rightarrow \mathrm{Pd}-\mathrm{CO}+\mathrm{H}_{2} \mathrm{O}$

$\mathrm{M}+\mathrm{H}_{2} \mathrm{O} \rightarrow \mathrm{M}-\mathrm{OH}+\mathrm{H}^{+}+\mathrm{e}^{-}$

$\mathrm{Pd}-\mathrm{CO}+\mathrm{M}-\mathrm{OH} \rightarrow \mathrm{Pd}+\mathrm{M}+\mathrm{CO}_{2}+\mathrm{H}^{+}+\mathrm{e}^{-}$

Furthermore, the catalytic structure and the support material also have a great impact on the catalytic activity. To further increase the utilization of the catalytic active sites, one efficient strategy is to disperse Pd based nanoparticles onto suitable support with large surface area and good electrical conductivity ${ }^{15}$. The traditional carbon-based support has been intensively employed such as the carbon black, carbon nanotube, carbon fiber; and the Vulcan XC 72R carbon is currently commercially applied ${ }^{16,17}$. Graphene is an ideal support for advanced catalysts because of its peculiar 2D nature and single-atom thickness, high chemical stability and ultra-high thermal conductivity ${ }^{18,19}$.
Some reports have been released on graphene support Pd catalyst for formic acid oxidation, while no amazing catalytic performance was realized probably due to the easy agglomeration and destruction of pure graphene ${ }^{15,20}$.

Luckily, graphene aerogel (GA), a rising star material, could overcome the above-mentioned problems by self-assembled 2D individual graphene sheets into 3D graphene aerogels 21,22 . Besides the virtues of the graphene alone, 3D graphene aerogel also exhibits several inherent merits including the efficient ions and molecules transportation and diffusion, large surface area, high electrical conductivity and chemical or electrochemical stability 23,24 . Therefore, they have potential applications in varied fields like energy storage, sensors, catalyst supports, etc ${ }^{25,26}$. Based on our experience, the ample oxygen-containing functional groups and conjugated domains might be useful for the formic acid molecular oxidation. To the best of our knowledge, rare reports are available in this field.

Platinum or Pd nanoparticles supported on heteroatom doped 3D graphene aerogel was tried for formic acid and methanol oxidation ${ }^{27,28}$, while the performance was still not satisfactory because of insufficient oxophilic species formation. By coupling the above inspirations, herein, we tried to fabricate the hybrid $\mathrm{PdNi} /$ graphene aerogel (PdNi/GA) catalyst by a simple freezingdrying/annealing approach to probe the formic acid oxidation ability. Because of the above mentioned many advantages, the as-fabricated $\mathrm{PdNi} / \mathrm{GA}$ catalyst displayed a very high catalytic efficacy to formic acid electro-oxidation. The high catalytic ability could be due to the larger surface provided by the $3 \mathrm{D}$ structure of graphene and the oxygen-containing groups on the graphene aerogel, which were beneficial to the removal of $\mathrm{CO}_{\mathrm{ad}}$ generated during the formic acid oxidation. This work provides a promising hybrid catalyst for direct formic acid fuel cells and extends the application of graphene aerogels.

\section{Experimental}

\subsection{Reagent}

All chemicals were purchased and used without further purification. Nickel acetate tetrahydrate $\left(\mathrm{NiC}_{4} \mathrm{H}_{6} \mathrm{O}_{4} \cdot 5 \mathrm{H}_{2} \mathrm{O}, \cdot \mathrm{AR}\right)$, Palladium chloride acid $\left(\mathrm{H}_{2} \mathrm{PdCl}_{4}, 30 \mathrm{mg} \cdot \mathrm{mL}^{-1}\right)$, Nafion (AR), were purchased from Shanghai Aladdin Bio-Chem Technology Co., LTD. Graphene was provided by the Institute of Coal Chemistry, Chinese Academy of Sciences. Milli-Q water 
(Thermo Fisher Scientific (USA) Co., Ltd) was used throughout the experiments.

\subsection{Catalyst fabrication}

$\mathrm{PdNi} / \mathrm{GA}$ was synthesized in the following steps: $30 \mathrm{mg}$ graphene was added into $6 \mathrm{~mL} \mathrm{H}_{2} \mathrm{O}$ with ultrasonic treatment for $1 \mathrm{~h}$. Then $40 \mathrm{mg}$ Nickel acetate tetrahydrate and $317 \mu \mathrm{L}$ Palladium chloride acid were added into the solution with a constant stir. The final solution was freeze-dried for $48 \mathrm{~h}$. The resulting black solid sample was annealed in $\mathrm{H}_{2}$ atmosphere at $500{ }^{\circ} \mathrm{C}$ for $2 \mathrm{~h}$ with a heating rate of $5^{\circ} \mathrm{C} \cdot \mathrm{min}^{-1} 29$. The reference sample of $\mathrm{Pd} / \mathrm{GA}$ was prepared with the same procedure without the addition of Nickel acetate tetrahydrate. A home-made Pd/C catalyst was also compared ${ }^{9}$. The Pd loading for all the catalyst was $20 \%$ (mass fraction).

\subsection{Characterization}

The sample was characterized on Bruker D8 advance X-ray diffraction (XRD) with $\mathrm{Cu} K_{\alpha}$ radiation. The morphology was examined with a FEI Sirion-200 scanning electron microscope (SEM) and a transmission electron microscope (TEM) operating at $200 \mathrm{kV}$. X-ray detector spectrum (EDS) images were obtained on a TECNAI G2 F30 transmission electron microscope (acceleration voltage: $300 \mathrm{kV}$ ). X-ray photoelectron spectroscopy (XPS) measurement was carried on an ECSALAB250Xi spectrometer with an $\mathrm{Al} K_{\alpha}$ radiation source.

\subsection{Electrochemical measurements}

All the electrochemical measurements were carried out in a conventional three electrode electrochemical cell by using an electrochemical workstation INTERFACE 1000 potentiostat/ galvanostat (GAMRY INSTRUMENTS Co. USA). The saturated calomel electrode ( $\left.\mathrm{SCE}, \mathrm{Hg} / \mathrm{Hg}_{2} \mathrm{Cl}_{2}\right)$ was used as the reference electrode. All of the potentials are relative to the SCE electrode. The graphite rod and the catalyst coated glassy carbon electrode (diameter $d=3 \mathrm{~mm}$ ) served as counter and working electrode, respectively. The catalyst ink was prepared as follows. $5 \mathrm{mg}$ catalyst and $50 \mu \mathrm{L}$ of $5 \%$ (mass fraction) Nafion solution was dispersed in $950 \mu \mathrm{L}$ of ethanol by sonication for at least 30 min to form a homogeneous ink. Then $10 \mu \mathrm{L}$ of the catalyst ink was loaded onto a pre-cleaned working electrode and let it dry naturally. The Pd loading on the glassy carbon electrode was $0.08 \mathrm{mg} \cdot \mathrm{cm}^{-2}$.

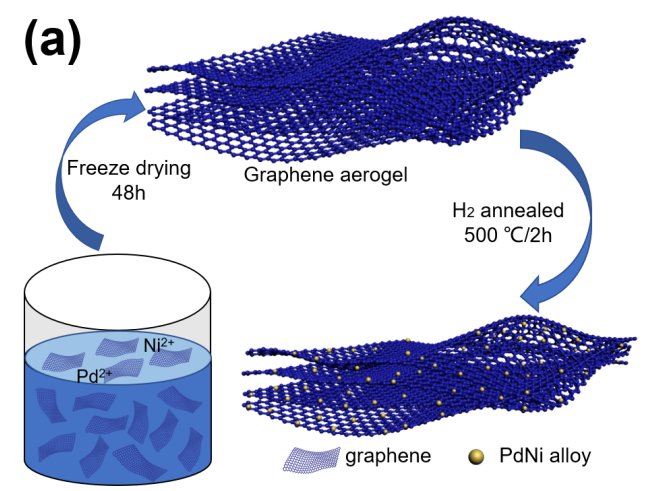

Cyclic voltammetry was carried out at room temperature in $0.5 \mathrm{~mol} \cdot \mathrm{L}^{-1} \mathrm{H}_{2} \mathrm{SO}_{4}$ containing a $0.5 \mathrm{~mol} \cdot \mathrm{L}^{-1} \mathrm{HCOOH}$ solution at the potential range between -0.2 and $1 \mathrm{~V}(v s \mathrm{SCE})$. The mass activity was calculated by normalizing the raw current to the Pd mass in the catalysts on the working electrode. Chronoamperometry (CA) experiment was performed in $40 \mathrm{~mL}$ of $0.5 \mathrm{~mol} \cdot \mathrm{L}^{-1} \mathrm{H}_{2} \mathrm{SO}_{4}$ containing $0.5 \mathrm{~mol} \cdot \mathrm{L}^{-1} \mathrm{HCOOH}$ solution at $0.1 \mathrm{~V}$ for $3600 \mathrm{~s}$. The electrochemical impedance spectrum (EIS) was done at $0.1 \mathrm{~V}$ to probe the charge transfer resistance recorded at the frequency range from $1000 \mathrm{kHz}$ to $10 \mathrm{mHz}$ with 15 points per decade. The amplitude of the sinusoidal potential signal was $5 \mathrm{mV}$. $\mathrm{CO}_{\mathrm{ad}}$ stripping voltammetry was measured in a $0.5 \mathrm{~mol} \cdot \mathrm{L}^{-1} \mathrm{H}_{2} \mathrm{SO}_{4}$ solution. $\mathrm{CO}$ was purged into the $\mathrm{H}_{2} \mathrm{SO}_{4}$ solution when the working electrode was kept at $0 \mathrm{~V}$ (vs SCE) for $15 \mathrm{~min}$ to allow the complete adsorption of $\mathrm{CO}$ onto the catalyst, and excess $\mathrm{CO}$ in the electrolyte was purged out with $\mathrm{N}_{2}$ for $15 \mathrm{~min}$. The amount of $\mathrm{CO}_{\mathrm{ad}}$ was evaluated by the integration of the $\mathrm{CO}_{\mathrm{ad}}$ stripping peak, assuming $420 \mu \mathrm{C} \cdot \mathrm{cm}^{-2}$ of coulombic charge required for the oxidation of adsorbed $\mathrm{CO}$ monolayer 30,31 . The electrochemically active surface area (ECSA) could be calculated with the following equation:

$\mathrm{ECSA}=Q / S l$

where $Q$ is the coulombic charge (in $\mathrm{mC}$ ) obtained from the $\mathrm{CO}$ stripping curve. $l$ is the loading of $\mathrm{Pd}$ on the surface of the electrode (in $\mathrm{mg}$ ) and $S$ is a proportionality constant of 420 $\mu \mathrm{C} \cdot \mathrm{cm}^{-2}$.

\section{Results and discussion}

The hybrid PdNi/GA catalyst fabrication approach was shown in Fig. 1a, that includes the graphene aerogel (GA) formation containing the $\mathrm{Pd}$ and $\mathrm{Ni}$ precursors and the subsequent thermal reduction of $\mathrm{Pd}^{2+}$ and $\mathrm{Ni}^{2+}$ at $500{ }^{\circ} \mathrm{C}$ in the $\mathrm{H}_{2}$ atmosphere (details see ESI). The crystalline structure of the concerned catalysts was probed by the powder X-ray diffraction (XRD) Technique (Fig. 1b). A home-made $\mathrm{Pd} / \mathrm{C}$ and $\mathrm{Pd} / \mathrm{GA}$ catalysts were used as control samples for comparison, and they both exhibited the face-centered cubic (fcc) structure of Pd with the characteristics peaks at $40.1^{\circ}, 46.6^{\circ}$ and $68.1^{\circ}$ from the (111), (200) and (220) crystalline planes ${ }^{32}$. The (002) facet of carbon support was indicated by the broad peak at $25^{\circ}$ for $\mathrm{Pd} / \mathrm{C}$ and the

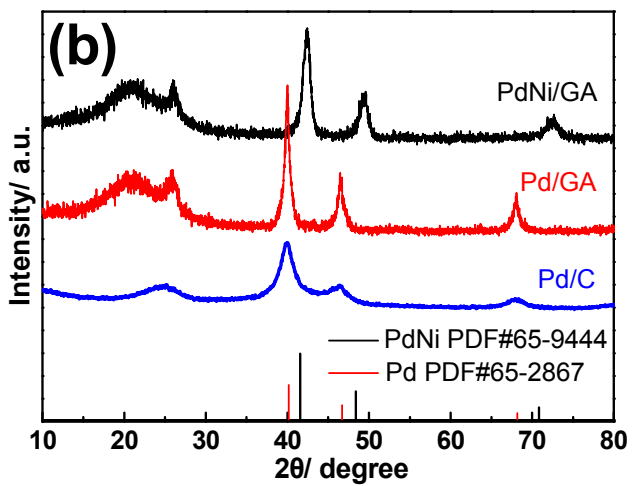

Fig.1 (a) The schematic diagram of synthetic procedure of PdNi/GA catalyst. (b) XRD pattern of PdNi/GA, Pd/GA and Pd/C catalysts. 
sharp peak at $21^{\circ}$ of $\mathrm{Pd} / \mathrm{GA}$ catalyst was due to the increased graphite degree of graphene after annealing. This peak was also indicated on $\mathrm{PdNi} / \mathrm{GA}$ catalyst and three main peaks were visible representing the PdNi alloy formation (PDF: 65-9444). The main diffraction peaks shifted to higher $2 \theta$ values relative to $\mathrm{Pd} / \mathrm{GA}$ catalysts, indicating the occurrence of a lattice contraction by forming PdNi alloy ${ }^{33}$.

The morphology of $\mathrm{PdNi} / \mathrm{GA}$ catalyst was further characterized by the scanning electron microscope. An interconnected 3D graphene network was displayed and PdNi alloy particles were visible by zooming in on the image (Fig. 2a, b). The interconnected $3 \mathrm{D}$ structure of $\mathrm{PdNi} / \mathrm{GA}$ was further confirmed by transmission electron microscopy (TEM) images (Fig. S1, Supporting Information (SI)). Nano particles were found in TEM image and the average particle size of $7.7 \mathrm{~nm}$ was indicated by the particle size distribution histogram (Fig. 2c and inset). The high-resolution TEM (HRTEM) image showed the interplanar spacing of $0.215 \mathrm{~nm}$ from the (111) facet of PdNi alloy, and the lattice fringe of $0.34 \mathrm{~nm}$ was indicated by the graphene layer (Fig. 2d). The selected area electron diffraction (SAED) showed the polycrystalline character with the evident spots and rings which can be indexed to the planes of PdNi (111), Pd (220), Pd (200), Pd (311) and Pd (420) in Fig. 2e. The X-ray detector spectrum (EDS) showed the concerned elements of Pd, $\mathrm{Ni}, \mathrm{C}$ and $\mathrm{O}$, and $\mathrm{Cu}$ was obviously from the copper support employed for the morphology observation (Fig. 2f). The distribution of these elements in the hybrid catalyst was demonstrated by the randomly selected areas of element mapping analysis (Fig. $2 \mathrm{~g}-\mathrm{k}$ ).

The surface chemical state of PdNi/GA was analyzed by X- ray photoelectron spectroscopy (XPS). The binding energy for all the spectrum was calibrated by the main peak of $\mathrm{C} 1 s$ at 284.6 $\mathrm{eV}^{34}$ (Fig. S2a (SI)) and the atomic percentage of Pd and Ni content on the surface was found to be $1: 1$ (Table S1 (SI)). The percentage of $\mathrm{C}-\mathrm{O}$ of $\mathrm{PdNi} / \mathrm{GA}$ was the highest, the existence of $-\mathrm{OH}$ was helpful for the removal of $\mathrm{CO}_{\mathrm{ad}}$ as well as the performance boosting for formic acid oxidation (Table S2 (SI)). The high resolution Pd $3 d$ spectrum included two bands of Pd $3 d_{5 / 2}$ and $3 d_{3 / 2}$, and each band can be deconvoluted into Pd (0) and Pd (II) species ${ }^{35}$. The binding energy shifted to a higher value was also found by comparing $\mathrm{Pd} / \mathrm{GA}$ and $\mathrm{Pd} / \mathrm{C}$ catalysts, indicating the much stronger support interaction of the GA than the carbon; because of the alloying effect, the binding energy of $\mathrm{PdNi} / \mathrm{GA}$ also shifted to the higher binding energy direction compared with Pd/GA catalyst (Fig. 3a). This observation was consistent with previous reports about the PdNi alloy ${ }^{36}$, and the shift has been attributed to more $d$-band vacancies of Ni than Pd, which would withdraw electrons from $\mathrm{Pd}$ and consequently increase the binding energy of Pd. For all the Pd spectra, the metallic Pd played a dominant role on the surface composition that might serve as the active sites for formic acid molecular adsorption and dissociation (Table S3 (SI)). Two components of Ni $2 p_{3 / 2}$ and Ni $2 p_{1 / 2}$ were visible for the spin-orbit splitting of high resolution Ni $2 p$ spectra (Fig. 3b). Each component was fitted by metallic Ni (0), Ni (II) and the satellite peaks. The metallic Ni from the PdNi alloy sat at 852.5 and $869.8 \mathrm{eV}$ respectively for $2 p_{3 / 2}$ and $2 p_{1 / 2}$, and the $\mathrm{Ni}$ (II) from the surface oxidation was visible at 855.3 and $873.2 \mathrm{eV}$ correspondingly. The easy formation of the $\mathrm{Ni}$ oxide species was thought beneficial to the oxygen-containing species generation during

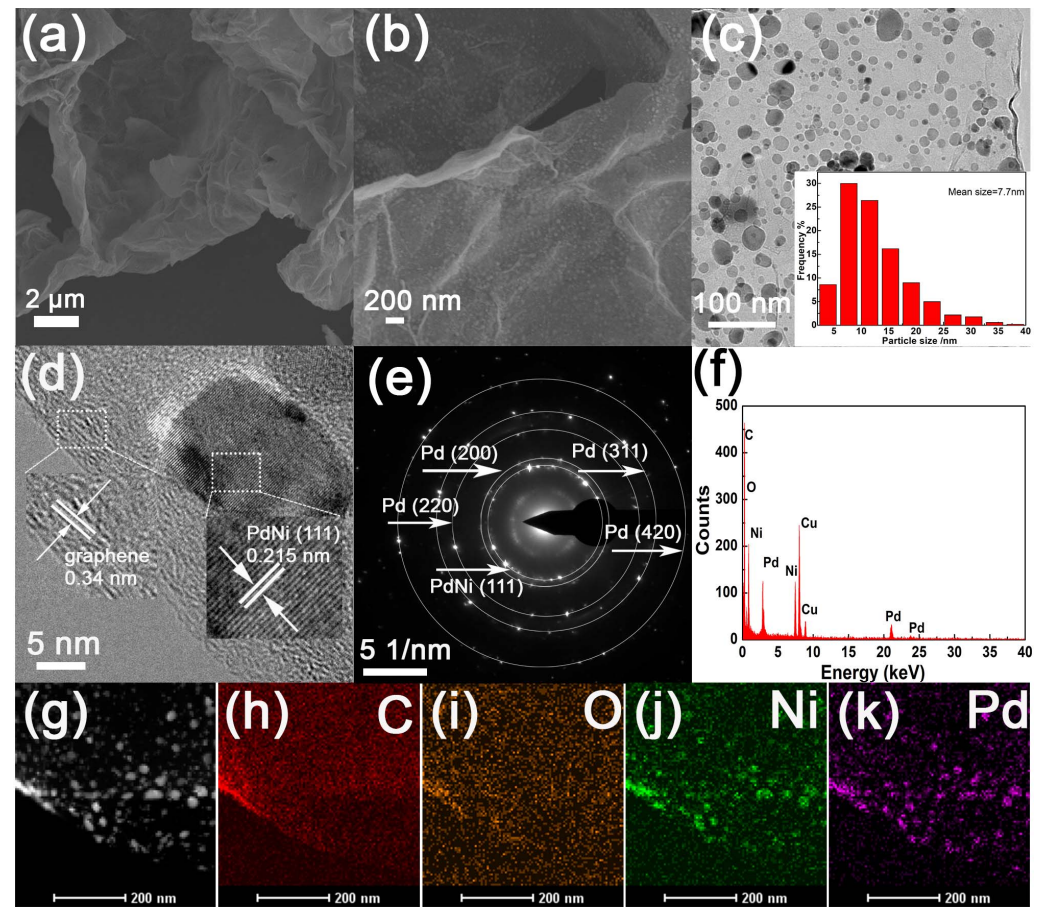

Fig. 2 (a, b) SEM images of PdNi/GA with different resolution. (c) TEM image of PdNi/GA (inset: particle size distribution histogram). (d) Highresolution TEM, (e) SAED and (f) EDS of PdNi/GA. (g) STEM and elemental mapping images of the PdNi/GA catalyst, (h) C, (i) N, (j) Ni, (k) Pd, (l) O. 

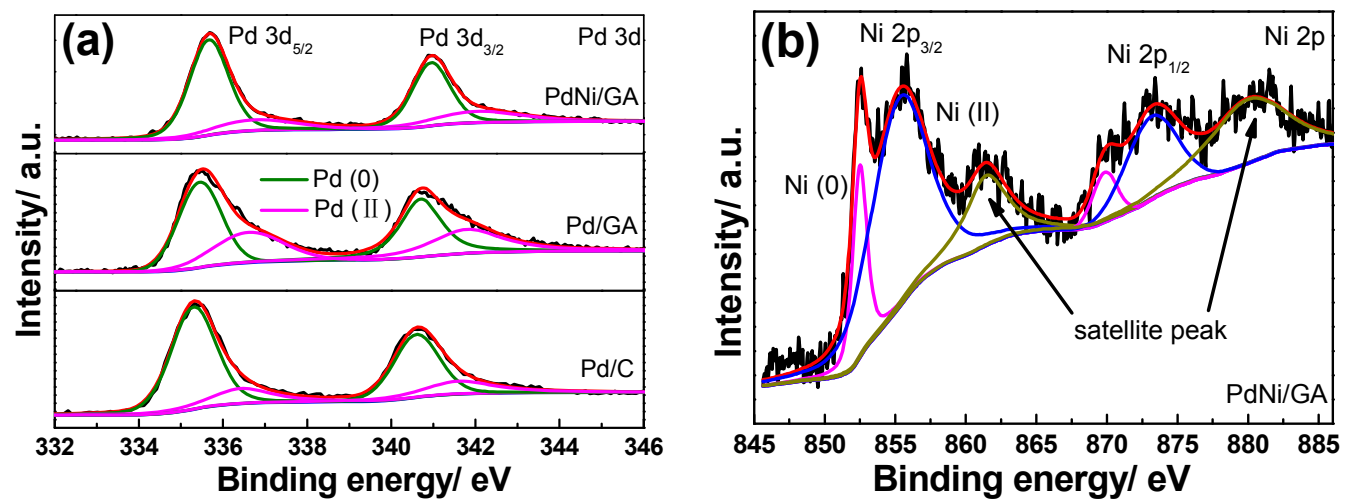

Fig. 3 (a) XPS spectra of Pd $3 d$ for PdNi/GA, Pd/GA and Pd/C catalysts, (b) XPS spectra of Ni $2 p$ for the PdNi/GA catalyst.
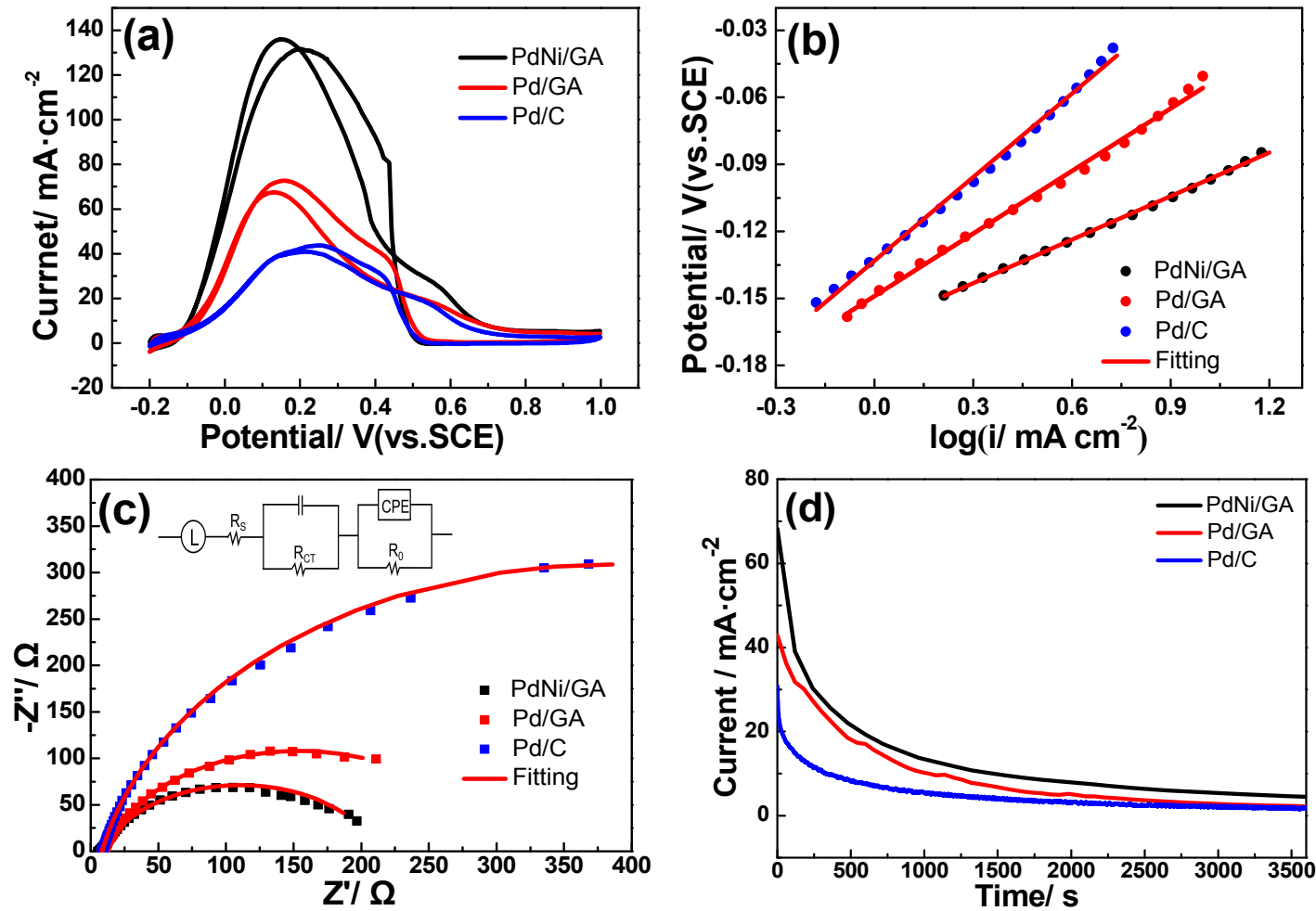

Fig. 4 (a) Cyclic voltammery curves of PdNi/GA, Pd/GA and Pd/C catalysts in $0.5 \mathrm{~mol} \cdot \mathrm{L}^{-1} \mathrm{H}_{2} \mathrm{SO}_{4} / 0.5 \mathrm{~mol} \cdot \mathrm{L}^{-1} \mathrm{HCOOH}$ solution at a scan rate of 50 $\mathrm{mV} \cdot \mathrm{s}^{-1}$; (b) the corresponding Tafel plots for PdNi/GA, Pd/GA and Pd/C catalysts; (c) Nyquist plots and (d) chronoamperometry curves of

$\mathrm{PdNi} / \mathrm{GA}, \mathrm{Pd} / \mathrm{GA}$ and $\mathrm{Pd} / \mathrm{C}$ catalysts in $0.5 \mathrm{~mol} \cdot \mathrm{L}^{-1} \mathrm{H}_{2} \mathrm{SO}_{4} / 0.5 \mathrm{~mol} \cdot \mathrm{L}^{-1} \mathrm{HCOOH}$ solution (inset of Fig. 4c: equivalent circuit).

the oxidation process as confirmed by the following $\mathrm{CO}$ stripping experiment and these species played an important role for the poisoning intermediates oxidation removal according to the bi-functional catalytic mechanism.

The electrochemical behaviors of these catalysts were compared in the background solution, and polycrystalline Pd behaviors were observed including the hydrogen ad/desorption peaks and Pd oxide and reduction peaks and a flat double layer range (Fig. S3 (SI)). The formic acid oxidation ability was probed by the cyclic voltammograms of $\mathrm{PdNi} / \mathrm{GA}, \mathrm{Pd} / \mathrm{GA}$ and $\mathrm{Pd} / \mathrm{C}$ in $0.5 \mathrm{~mol} \cdot \mathrm{L}^{-1} \mathrm{H}_{2} \mathrm{SO}_{4} / 0.5 \mathrm{~mol} \cdot \mathrm{L}^{-1} \mathrm{HCOOH}$ solution (Fig. 4a). The catalytic merits can be evaluated by the peak current density, among the studied catalysts, $\mathrm{PdNi} / \mathrm{GA}$ catalyst displayed the highest peak current density of $136 \mathrm{~mA} \cdot \mathrm{cm}^{-2}$, which was 2 and 3.45 times of that of $\mathrm{Pd} / \mathrm{GA}\left(68 \mathrm{~mA} \cdot \mathrm{cm}^{-2}\right)$ and $\mathrm{Pd} / \mathrm{C}(39.4$
$\mathrm{mA} \cdot \mathrm{cm}^{-2}$ ), respectively. Additionally, the current density of $\mathrm{PdNi} / \mathrm{GA}$ was also superior or comparable to those of most recently reported Pd based catalysts (Table S4 (SI)). Tafel slope was achieved by fitting the Tafel range of the quasi-static linear scanning voltammetry curve at a low scanning rate of $5 \mathrm{mV} \cdot \mathrm{s}^{-1}$. The Tafel slope of PdNi/GA catalyst was $64 \mathrm{mV} \cdot \mathrm{dec}^{-1}$, smaller than that of $\mathrm{Pd} / \mathrm{GA}\left(93 \mathrm{mV} \cdot \mathrm{dec}^{-1}\right)$ and $\mathrm{Pd} / \mathrm{C}\left(158 \mathrm{mV} \cdot \mathrm{dec}^{-1}\right)$ catalyst (Fig. 4b). The Tafel slope with the value of $60 \mathrm{mV} \cdot \mathrm{dec}^{-1}$ indicated the catalytic mechanism determined by dehydrogenation process 37 and subsequent oxidation of adsorbed $\mathrm{CO}^{38,39}$. The kinetics can also be analyzed by the slope from the linear fitting of the peak current vs. the square root of the scan rates (Fig. S4 (SI)), and the larger value of 9.7 was obtained on $\mathrm{PdNi} / \mathrm{GA}$ catalyst, indicating much higher catalytic kinetics. The charge transfer resistance was analyzed by 
electrochemical impedance spectroscopy (EIS) recorded for formic acid oxidation at $0.1 \mathrm{~V}$ (Fig. 4c). Generally, the charge transfer resistance could be indicated by the semicircle in the intermediate frequency region, the larger the diameter, the larger the charge transfer resistance. The details could be obtained by EIS date fitting to display the information of the electrodecatalyst-electrolyte interface. An equivalent circuit (inset of Fig. $4 c)$ was used that included the general electrical elements. The element of $L$ was from the inductance of an external circuit, and $R_{\mathrm{S}}$ symbolized the uncompensated solution resistance, $R_{\mathrm{CT}}$ was for the charge transfer resistance and $R_{0}$ came from the contact resistance between the catalyst and the glassy carbon electrode, and constant phase elements (CPE) of double layer capacitor were required for the fitting. The uncompensated solution resistance $\left(R_{\mathrm{S}}\right)$ was about $6.8 \Omega$ for all the electrode indicating a fair comparison, and the smallest $R_{\mathrm{CT}}$ value of $206 \Omega$ for $\mathrm{PdNi} / \mathrm{GA}$ catalyst indicated the fastest charge transfer ability (Table S5 (SI)). The stability of the catalysts was evaluated by the chronoamperometry (CA) experiment for $3600 \mathrm{~s}$ at the constant potential of $0.1 \mathrm{~V}$ (Fig. 4d). After the $3600 \mathrm{~s}$ test, the final current density is $5 \mathrm{~mA} \cdot \mathrm{cm}^{-2}$ for $\mathrm{PdNi} / \mathrm{GA}$, which was 1.87 and 2.8 times of $\mathrm{Pd} / \mathrm{GA}\left(2.67 \mathrm{~mA} \cdot \mathrm{cm}^{-2}\right)$ and $\mathrm{Pd} / \mathrm{C}\left(1.8 \mathrm{~mA} \cdot \mathrm{cm}^{-2}\right)$ catalysts, respectively. Though $\mathrm{PdNi} / \mathrm{GA}$ catalyst showed much better stability than $\mathrm{Pd} / \mathrm{GA}$ and $\mathrm{Pd} / \mathrm{C}$ catalysts, further effort is still in need.

The anti-poisoning ability of the high-performance catalyst for formic acid oxidation was very important. Here, the anti-CO poisoning ability was examined by $\mathrm{CO}$-stripping technique and the amount of catalytic active sites was estimate by electrochemical active surface area (ECSA). The onset and peak oxidation potential of adsorbed $\mathrm{CO}\left(\mathrm{CO}_{\mathrm{ad}}\right)$ could be used to evaluate the anti-poisoning ability; the lower potential represents the higher $\mathrm{CO}_{\mathrm{ad}}$ oxidation ability and the higher anti-poisoning ability. Fig. 5 showed the $\mathrm{CO}$ stripping curves on $\mathrm{PdNi} / \mathrm{GA}$, $\mathrm{Pd} / \mathrm{GA}$ and $\mathrm{Pd} / \mathrm{C}$ catalysts. In the lower potential region $(-0.2-$ $0 \mathrm{~V}$ ) of the first sweep cycle, the absence of hydrogen desorption peaks confirmed the $\mathrm{CO}$ adsorption on the active sites. By increasing the potential with the positive sweep, the CO oxidation peaks were observed on all the electrodes. However,

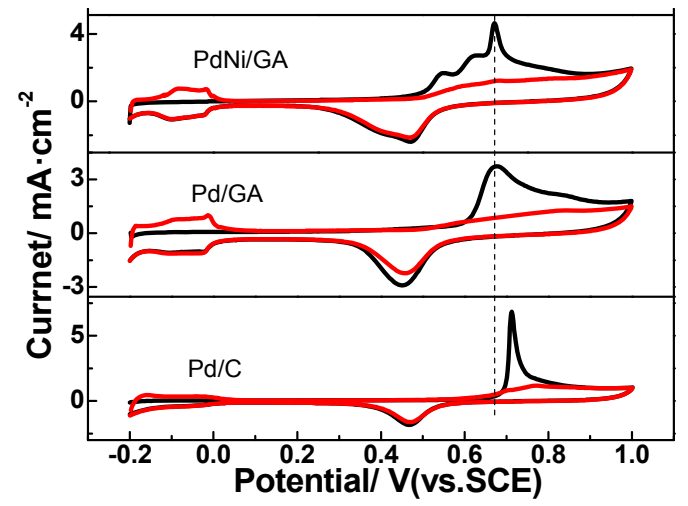

Fig. $5 \mathrm{CO}_{\text {ad }}$ stripping voltammograms of PdNi/GA, Pd/GA and $\mathrm{Pd} / \mathrm{C}$ in $0.5 \mathrm{~mol} \cdot \mathrm{L}^{-1} \mathrm{H}_{2} \mathrm{SO}_{4}$ solution at the scan rate of $20 \mathrm{mV} \cdot \mathrm{s}^{-1}$. the $\mathrm{CO}$ oxidation peaks disappeared and the hydrogen adsorption/desorption peaks recovered in the second sweep cycle, indicating the adsorbed $\mathrm{CO}$ on the surface of catalysts was completely oxidized. The ECSAs of PdNi/GA, Pd/GA, and Pd/C catalysts were calculated to be $65.12,63.50$, and $56.00 \mathrm{~m}^{2} \cdot \mathrm{g}^{-1}$. Namely, PdNi/GA possessed much larger ECSA than Pd/GA and $\mathrm{Pd} / \mathrm{C}$ catalysts, thereby offering more active sites for FAOR ${ }^{40}$. The GA supported Pd and PdNi catalyst possessed similar ECSA but larger than that of carbon supported Pd catalyst, which might result from the $3 \mathrm{D}$ structure of graphene aerogel, which could provide a larger surface to support and expose the active sites. $\mathrm{PdNi} / \mathrm{GA}$ showed the lowest onset potential of $0.49 \mathrm{~V}$ and oxidation peak potential of $0.67 \mathrm{~V}$ for CO oxidation (Table S6 (SI)), which indicated the highest anti-poisoning ability. The mass activity and specific activity were also calculated for the catalytic efficiency evaluation. PdNi/GA catalyst had the highest mass activity of $1699 \mathrm{~mA} \cdot \mathrm{mg}^{-1}$ compared to $\mathrm{Pd} / \mathrm{GA}$ (851 $\left.\mathrm{mA} \cdot \mathrm{mg}^{-1}\right)$ and $\mathrm{Pd} / \mathrm{C}\left(537 \mathrm{~mA} \cdot \mathrm{mg}^{-1}\right)$ catalysts. The specific activity of PdNi/GA was $2.6 \mathrm{~mA} \cdot \mathrm{cm}^{-2}$, which was 1.94 and 2.7 times of $\mathrm{Pd} / \mathrm{GA}\left(1.34 \mathrm{~mA} \cdot \mathrm{cm}^{-2}\right)$ and $\mathrm{Pd} / \mathrm{C}\left(0.96 \mathrm{~mA} \cdot \mathrm{cm}^{-2}\right)$ catalysts (Fig. S5 (SI)).

\section{Conclusions}

Herein, PdNi/GA catalyst fabricated by a simple freezingdrying/annealing approach was demonstrated to have high catalytic efficiency for formic acid electrooxidation. The 3D structure of graphene aerogel could provide a larger surface to support and expose active PdNi alloy and the oxophilic property of graphene aerogel and $\mathrm{Ni}$ species are beneficial to the poisoning intermediates removal during the formic acid oxidation. Driven by the binary synergism and electronic effect, $\mathrm{PdNi} / \mathrm{GA}$ catalyst displayed a larger peak current density of 136 $\mathrm{mA} \cdot \mathrm{cm}^{-2}$, which was 2 and 3.45 times greater than Pd/GA (68 $\left.\mathrm{mA} \cdot \mathrm{cm}^{-2}\right)$ and $\mathrm{Pd} / \mathrm{C}\left(39.4 \mathrm{~mA} \cdot \mathrm{cm}^{-2}\right)$, respectively. The high activity and stability make it have potential applications in direct formic acid fuel cell if properly optimized.

Supporting Information: available free of charge via the internet at http://www.whxb.pku.edu.cn.

\section{References}

(1) Feng, L.; Chang, J.; Jiang, K.; Xue, H.; Liu, C.; Cai, W. B.; Xing, W.; Zhang, J. Nano Energy 2016, 30, 355. doi: 10.1016/j.nanoen.2016.10.023

(2) Ong, B. C.; Kamarudin, S. K.; Basri, S. Int. J. Hydrogen Energy 2017, 42, 10142. doi: 10.1016/j.ijhydene.2017.01.117

(3) Yang, J. L. Acta Phys. -Chim. Sin. 2020, 36, 2003010. [杨金龙. 物理 化学学报, 2020, 36, 2003010.] doi: 10.3866/PKU.WHXB202003010

(4) Lü, Y.; Song, Y. J.; Liu, H. Y.; Li, H. Q. Acta Phys. -Chim. Sin. 2017, 33, 283. [吕洋, 宋玉江, 刘会园, 李焕巧. 物理化学学报, 2017, 33, 283.] doi: 10.3866/PKU.WHXB201611071 
(5) Li, Q. W.; Wei, Z. D.; Chen, S. G.; Qi, X. Q.; Liu, X.; Ding, W.; Ma, Y. Acta Phys. -Chim. Sin. 2011, 27, 2857. [李庆武, 魏子栋, 陈四国, 齐学强, 柳晓, 丁炜, 马宇. 物理化学学报, 2011, 27, 2857.] doi: 10.3866/PKU.WHXB20112857

(6) Hu, S.; Che, F.; Khorasani, B.; Jeon, M.; Yoon, C. W.; McEwen, J. S.; Scudiero, L.; Ha, S. Appl. Catal. B: Environ. 2019, 254, 685. doi: 10.1016/j.apcatb.2019.03.072

(7) Romero Hernández, A.; Arce Estrada, E. M.; Ezeta, A.; Manríquez, M. E. Electrochim. Acta 2019, 327, 134977. doi: 10.1016/j.electacta.2019.134977

(8) Fang, B.; Feng, L. G. Acta Phys. -Chim. Sin. 2020, 36, 1905023. [方 波, 冯立纲. 物理化学学报, 2020, 36, 1905023.] doi: 10.3866/PKU.WHXB201905023

(9) Wang, F.; Xue, H.; Tian, Z.; Xing, W.; Feng, L. J. Power Sources 2018, 375, 37. doi: 10.1016/j.jpowsour.2017.11.055

(10) Jiang, K.; Zhang, H. X.; Zou, S.; Cai, W. B. Phys. Chem. Chem. Phys. 2014, 16, 20360. doi: 10.1039/C4CP03151B

(11) Liu, H.; Yang, D.; Bao, Y.; Yu, X.; Feng, L. J. Power Sources 2019, 434, 226754. doi: 10.1016/j.jpowsour.2019.226754

(12) Bao, Y.; Wang, F.; Gu, X.; Feng, L. Nanoscale 2019, 11, 18866. doi: $10.1039 /$ C9NR07158J

(13) Bin, D.; Yang, B.; Ren, F.; Zhang, K.; Yang, P.; Du, Y. J. Mater. Chem. A 2015, 3, 14001. doi: 10.1039/C5TA02829A

(14) Chen, W.; Xue, J.; Bao, Y.; Feng, L. Chem. Eng. J. 2020, 381, 122752. doi: 10.1016/j.cej.2019.122752

(15) Zhang, X.; Zhu, J.; Tiwary, C. S.; Ma, Z.; Huang, H.; Zhang, J.; Lu, Z.; Huang, W.; Wu, Y. ACS Appl. Mater. Interfaces 2016, 8, 10858. doi: $10.1021 /$ acsami.6b01580

(16) Siller-Ceniceros, A. A.; Sánchez-Castro, M. E.; Morales-Acosta, D.; Torres-Lubian, J. R.; Martínez G, E.; Rodríguez-Varela, F. J. Appl. Catal. B: Environ. 2017, 209, 455. doi: 10.1016/j.apcatb.2017.03.023

(17) Tzorbatzoglou, F.; Brouzgou, A.; Jing, S.; Wang, Y.; Song, S.; Tsiakaras, P. Int. J. Hydrogen Energy 2018, 43, 11766. doi: 10.1016/j.ijhydene.2018.02.071

(18) Perivoliotis, D. K.; Tagmatarchis, N. Carbon 2017, 118, 493. doi: 10.1016/j.carbon.2017.03.073

(19) Zhang, H.; Zhai, C.; Gao, H.; Fu, N.; Zhu, M. J. Colloid Interface Sci. 2019, 547, 102. doi: 10.1016/j.jcis.2019.03.090

(20) Zhang, Z.; Gong, Y.; Wu, D.; Li, Z.; Li, Q.; Zheng, L.; Chen, W.; Yuan, W.; Zhang, L. Y. Int. J. Hydrogen Energy 2019, 44, 2731. doi: 10.1016/j.ijhydene.2018.12.004

(21) Kotal, M.; Kim, J.; Oh, J.; Oh, I. K. Front. Mater. 2016, 3. doi: 10.3389 /fmats.2016.00029

(22) Zhang, X.; Han, Y.; Huang, L.; Dong, S. ChemSusChem 2016, 9 ,
3049. doi: $10.1002 /$ cssc. 201600904

(23) Zhao, L.; Wang, Z. B.; Li, J. L.; Zhang, J. J.; Sui, X. L.; Zhang, L. M. Electrochim. Acta 2016, 189, 175. doi: 10.1016/j.electacta.2015.12.072

(24) Zhang, X.; Hao, N.; Dong, X.; Chen, S.; Zhou, Z.; Zhang, Y.; Wang, K. $R S C A d v$. 2016, 6, 69973. doi: 10.1039/C6RA12562J

(25) Xia, W.; Qu, C.; Liang, Z.; Zhao, B.; Dai, S.; Qiu, B.; Jiao, Y.; Zhang, Q.; Huang, X.; Guo, W.; et al. Nano Lett. 2017, 17, 2788. doi: 10.1021/acs.nanolett.6b05004

(26) Fu, G.; Yan, X.; Chen, Y.; Xu, L.; Sun, D.; Lee, J. M.; Tang, Y. Adv. Mater. 2018, 30, 1704609. doi: 10.1002/adma.201704609

(27) Çögenli, M. S.; Ayșe, B. Y. Mater. Res. Express 2018, 5, 075513. doi: 10.1088/2053-1591/aad0e8

(28) Çögenli, M. S.; Bayrakçeken Yurtcan, A. Int. J. Hydrogen Energy 2020, 45, 650. doi: 10.1016/j.jhydene.2019.10.226

(29) Zhao, S.; Yin, H.; Du, L.; Yin, G.; Tang, Z.; Liu, S. J. Mater. Chem. A 2014, 2, 3719. doi: 10.1039/C3TA14809B

(30) Wang, F.; Yu, H.; Tian, Z.; Xue, H.; Feng, L. J. Energy Chem. 2018, 27, 395. doi: 10.1016/j.jechem.2017.12.011

(31) Bao, Y.; Liu, H.; Liu, Z.; Wang, F.; Feng, L. Appl. Catal. B: Environ. 2020, 274, 119106 . doi: 10.1016/j.apcatb.2020.119106

(32) Sun, L.; Liao, B.; Ren, X.; Li, Y.; Zhang, P.; Deng, L.; Gao, Y. Electrochim. Acta 2017, 235, 543. doi: 10.1016/j.electacta.2017.03.159

(33) Lohrasbi, E.; Javanbakht, M.; Mozaffari, S. A. Ind. Eng. Chem. Res. 2016, 55, 9154. doi: 10.1021/acs.iecr.6b00980

(34) Pei, C.; Ding, R.; Yu, X.; Feng, L. ChemCatChem 2019, 11, 4617. doi: $10.1002 /$ cctc. 201900886

(35) Lim, E. J.; Kim, H. J.; Kim, W. B. Catal. Commun. 2012, 25, 74. doi: 10.1016/j.catcom.2012.04.011

(36) Xu, C.; Liu, Y.; Hao, Q.; Duan, H. J. Mater. Chem. A 2013, 1, 13542. doi: $10.1039 / \mathrm{C} 3 \mathrm{TA} 12765 \mathrm{~F}$

(37) Wang, Y.; He, Q.; Wei, H.; Guo, J.; Ding, K.; Wang, Q.; Wang, Z.; Wei, S.; Guo, Z. Electrochim. Acta 2015, 184, 452. doi: 10.1016/j.electacta.2015.10.046

(38) Lebedeva, N. P.; Koper, M. T. M.; Feliu, J. M.; van Santen, R. A. J. Electroanal. Chem. 2002, 524-525, 242. doi: 10.1016/S0022-0728(02)00669-1

(39) Seland, F.; Tunold, R.; Harrington, D. A. Electrochim. Acta 2008, 53, 6851. doi: 10.1016/j.electacta.2007.12.021

(40) Li, S.; Dong, Z.; Yang, H.; Guo, S.; Gou, G.; Ren, R.; Zhu, Z.; Jin, J.; Ma, J. Chem. Euro. J. 2013, 19, 2384. doi: $10.1002 /$ chem. 201203686 